\title{
Improving Student's Coding Skill with Gamification Website-based Program
}

\author{
Rahmat Rizal Andhi* \\ Dept. Of Electrical Engineering \\ Universitas Riau \\ Pekanbaru, Indonesia \\ rahmat.rizal@lecturer.unri.ac.id
}

\author{
Edi Susilo \\ Dept. Of Electrical Engineering \\ Universitas Riau \\ Pekanbaru, Indonesia \\ edi.susilo@lecturer.unri.ac.id
}

\author{
Salhazan Nasution \\ Dept. Of Electrical Engineering \\ Universitas Riau \\ Pekanbaru, Indonesia \\ salhazan.nasution@lecturer.unri.ac.id
}

*Corresponding author: rahmat rizal andhi, rahmat.rizal@lecturer.unri.ac.id

\begin{abstract}
People's dependence on digital technology has increased rapidly since the global Covid-19 pandemic. This causes the world's need for digital products and human resources to make digital products higher. Informatics Engineering Program is one of the providers of human resources who are proficient in the field of information technology. One of the basic skills that must be possessed to create digital products is programming or coding skills. The more skilled a person is at typing and understanding coding, the more complex the digital products he can create. This is why the coding ability of students in the Informatics Engineering Program must be improved. This website-based coding training program aims to improve the coding skills of Informatics Engineering students with interesting and fun gamification methods. Gamification methodology will greatly benefit student of Informatics Engineering Program in Riau University to improve his or her coding skill without consuming too much time and energy.
\end{abstract}

Keywords - coding, eLearning, education, gamification, tools

\section{INTRODUCTION}

Informatics Engineering is a higher education department that studies and applies the principles of computer science and mathematical analysis in designing, testing, developing and evaluating operating systems, software, and computer performance. In other words, this field of study will discuss related to data processing by utilizing computer technology that uses logical principles and processes. Various branches of education in the field of information technology and computers can be seen in the picture below.

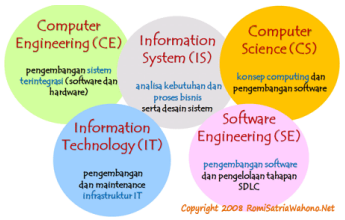

Fig. 1. Various Branch of Information Technology Education Field

The interest in Informatics Engineering is always increasing every year. At the University of Riau itself, the number of applicants for the Informatics Engineering study program is the largest after the Faculty of Medicine, which is 1147 people with only 35 seats available, resulting in a ratio of 1 : 32. This is reinforced by the current state of the Covid-19 pandemic which has increased the dependence of all fields, especially the education sector, on information technology.

Referring to the IEEE Computing Curricula 2005, students under the discipline of computing may not understand the problem of information systems or database theory, but all students are required to have coding skills. Coding and programming skills are included in Software Methods and Technologies, which are very crucial skills for Informatics Engineering students where the focus of study and practice revolves around the use of information technology to solve problems that arise in everyday life.

Unfortunately, based on the data I obtained from initial field observations of 42 new students of the Informatics Engineering study program, Riau University, only 5 people could do the simplest coding, which means only 11.63 percent of students. While referring to the composition of the curriculum for general and main courses of the Informatics Engineering Study Program, University of Riau, which amounted to 144 credits, 81.25 percent (117 credits) required coding skills from the students. You can imagine the difficulties that will be faced by students in participating in the lecture process at the Informatics Engineering Study Program in the next 4-5 years. This fact prompted the author to raise this issue, namely about coding training in the early days of lectures to improve the coding skills of students in the Informatics Engineering study program for the smooth process of the student's study.

\section{Methodology}

The term "Gamification" is first used by Nick Pelling in a presentation at a TED (Technology, Entertainment, Design) event. Gamification is a learning approach using elements in games or video games with the aim of motivating students in the learning process and maximizing feelings of enjoyment and engagement with the learning process, besides that this media can be used to capture things that interest students and inspire them. to continue learning. Gamification is the use of game mechanics to provide practical solutions by building 
specific group engagement [1]. In more detail [2] defines gamification as a concept that uses game-based mechanics, aesthetics and game thinking to engage people, motivate action, promote learning and solve problems. Glover concluded that gamification provides additional motivation to ensure that learners (learners) participate in complete learning activities [3]. Engagement can be interpreted as a willingness to participate, Frederick defines student engagement as a meta-construction act that includes the involvement of students' behavior, emotions and cognitive in learning [4]. Like a game that allows players to restart or replay, making mistakes that can be corrected so that players are not afraid of failure and increase their attachment to the game. Gamification works by making technology more attractive, encouraging users to engage in desired behaviors, showing the way to mastery and autonomy, helping to solve problems and not becoming a distraction, and taking advantage of psychological tendencies. humans to engage in games. According to Zichermann gamification is the process of thinking games and game mechanics to involve users and solve problems [5], [6]. A more general definition gamification is the use of design elements that make up a game in a non-game context [7]. The following are the steps for applying gamification in learning:

i. Know the learning objectives

ii. Determine the big idea

iii. Create a game scenario

iv. Design learning activities

v. Build groups

vi. Apply game dynamics

The following are the steps to carry out gamification in learning, namely:

i. Break the subject matter into specific parts. Give a quiz at the end of each section and award participants/students with a virtual badge if they pass the quiz.

ii. Separate the material into different and tiered levels. So, as their learning progresses, students get badges and higher levels are unlocked so they can learn new material.

iii. Record the scores obtained in each section. This is intended for students to focus on improving their overall score.

iv. Give rewards such as badges, certificates, achievements that can be posted on students' social media or on campus/company internal websites.

v. Make the level/level sensitive to date or time, so they have to check every day, every week, or every month for new challenges.

vi. Create task groups so students can collaborate together to complete projects.

vii. Introduce the concept of 'quest' or 'epic meaning', where students can submit their work that can strengthen learning or cultural norms.

The gamification learning model has several advantages over other learning models, including:

i. Learning becomes more fun.

ii. Encourage students to complete their learning activities. iii. Helping students focus and understand the material being studied.

iv. Provide opportunities for students to compete, explore and excel in class.

According to M. Atwi [8], there is 12 principles of Education, which is:

i. A new response is repeated as a result of that response

ii. Behavior is under the influence of environmental conditions

iii. Behavior result will be lost if it is not reinforced

iv. Response to limited signs will be transferred on a limited basis

v. Generalization and differentiation are the basis for complex learning

vi. Mental status to attend lessons will affect persistence of students during learning process

vii. Learning activities are divided into small steps

viii. Simplify complex materials using model

ix. High level skills are formed from simpler base skill

x. Learning become faster and more efficient when students being notified of his/her progress

xi. Everyone's development and learning speed is different

xii. With preparations, student can organize their own learning activities

Research shows that learning outcomes and learning output are significantly influenced by student's knowledge before they used other tools [9]. Social media has been able to show its efficiency in e-learning, in contrast to gamification which has just shown its potential as tool for student motivation in learning process using e-learning [10].

In 2016, Luis de Marcos once again conducted a study on effectiveness of learning approaches using social and games. This time, he conducted experiments using 4 approaches which is: educational games, gamification, social networking and social gamification. According to experimental study, social gamification has better results when used at the initial and evaluation stage of the experiment. This study focuses on the difference between practical skills where new approaches have more appropriate results and conceptual knowledge where mixed learning has better result [11]. Adopting information technology does not always lead to high motivation. Hoskins and van Hoof reported a study in Web Tools (WebCT) program that only highly motivated and educated learners can benefit from multimedia [12].

\section{DATA FINDING}

Students are the forerunner of the birth of the output of a study program, while graduates are the highly anticipated output, as evidence that the learning process in a study program has been successfully carried out by producing graduates. Therefore, data regarding students and graduates of the UNRI Informatics Engineering Study Program is very important data so that it can be a reference for Stakeholders, Government/Private Agencies, Schools and other Parties regarding actual information about Students and Graduates of the Informatics Engineering Study Program. UNRI. The following is a comparison graph of the number of enthusiasts 
and the number of students who graduated as students of the Informatics Engineering Study Program, Riau University.

\section{Comparison of Candidate and Graduated Student Informatics Program UNRI}

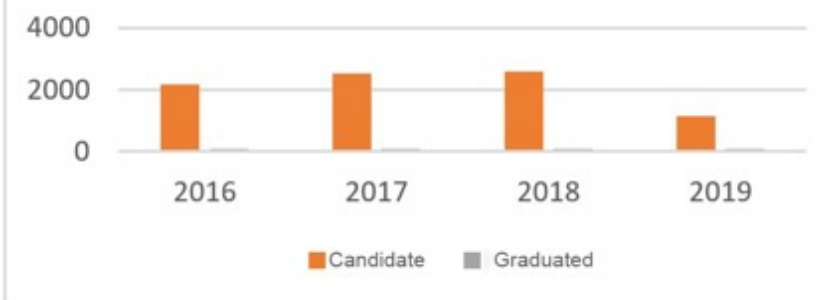

Fig. 2. Graphical Comparison of Candidate and Graduated Student Informatics Program UNRI

From a total of 89 students who were accepted in the $2020 / 2021$ academic year, the authors took 42 people as samples. Based on initial observations in the form of questionnaire testing conducted on 42 students, the authors tested these students to write the simplest coding, namely "Hello World" with the programming language they know. The result is only 5 out of 42 students who can write coding correctly.

The curriculum of the Informatics Engineering Study Program was compiled based on Government Regulation No. 8 of 2012 concerning the National Qualification Framework and the results of academic studies [13] conducted jointly in the 2015 Association of Informatics and Computer Universities (APTIKOM) concerning the KKNI of the Informatics and Computer Sciences Cluster as a standard of competence graduates nationally. Meanwhile, the international standard Informatics Engineering Study Program curriculum refers to the 2005 Curricula issued by the (Association for Computing Machinery) and the IEEE (Institute of Electrical and Electronics Engineers) which are international best practice standards in the field of informatics and computers [14].

The UNRI Informatics Engineering Study Program offers three areas of expertise, namely Intelligent Computing and Visualization, Network-based Computing and Software Engineering [9]. Students are required to take elective courses according to their area of expertise and interests. The following is the number of practicum courses that must be taken by students of the Informatics Engineering Study Program, Riau University.

Based on the composition of the curriculum, 117 of the 144 credits or 81.25 percent require good coding skills from the participants [15]. Thus, it is certain that most of the new students from the Informatics Engineering Study Program will experience difficulties in the learning process for the next 4-5 years.

\section{RESUlt AND Discussion}

The elements of gamification that can be used include:

1. Level

- Level is a limited space that can be explored by players in a game (game) in achieving certain goals.
- This coding training program has 10 levels

- The mission of each level is to type the coding syntax correctly until the health bar/loading bar is full

- If the health bar/loading bar is full, the participant will move to the next level

- If participants successfully complete 10 levels, then the game (game) will be over (game over)

2. Category

- The main categories are divided into 3 namely Desktop Developers, Mobile Developers and Website Developers

- The sub-category of the main category is the programming language of that category.

- For example, $\mathrm{C}++/ \mathrm{C} \#$ programming language for Desktop, Java programming language for Mobile and HTML programming language for Website.

3. Score

- $\quad$ Each correct typing of coding syntax will be worth 10 points

- $\quad$ After the game (game) ends, the total syntax that was successfully typed by the player multiplied by 10 is the final score of the player.

\section{Rewards and Acknowledgments}

For now, the rewards obtained by students of the Informatics Engineering Study Program at the University of Riau are in the form of additional points in the Basic programming course if they reach the maximum score.

\section{Challenge}

- The difficulty level of the program will increase as the level played by the player increases

- The difficulty level of each level is in the form of the time given to type the coding syntax and the number of characters in each coding syntax.

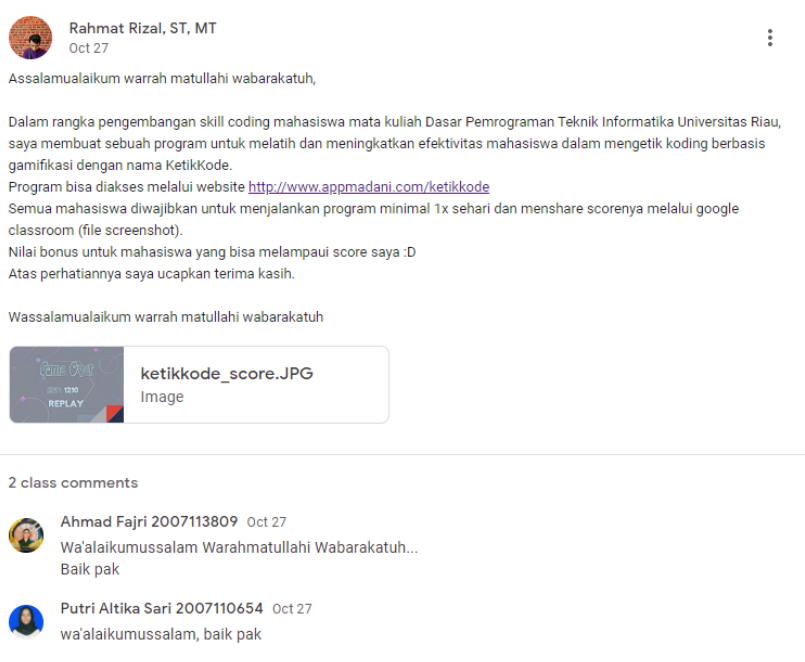

Fig. 3. Coding Testing Invitation

This initial implementation lasts for five days where every day each training participant runs a training program and uploads their scores. The following is a documentation of the 
invitation, technical guidance and score results from the trainees.

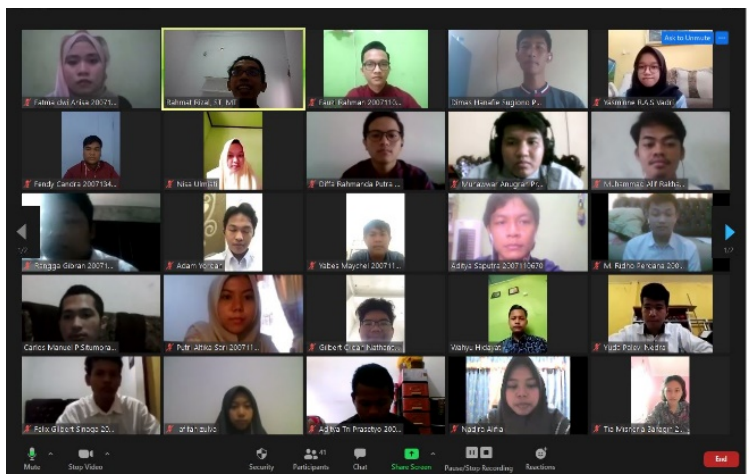

Fig. 4. Coding Training Technique Guidance
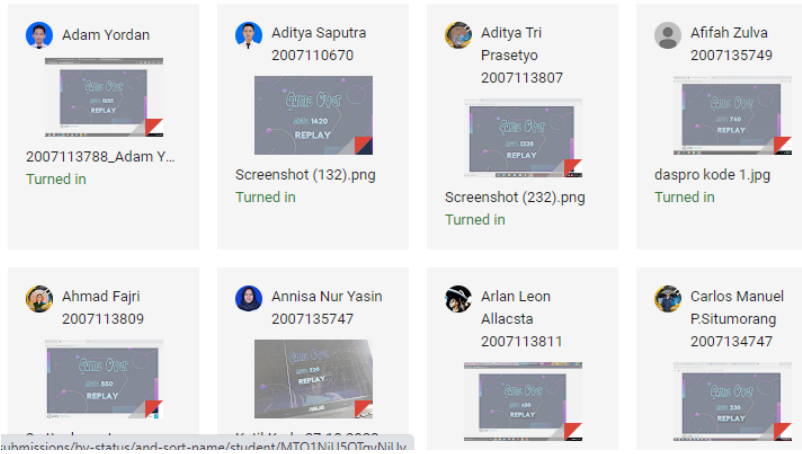

Fig. 5. Coding Training Participants Score Data

After the implementation and data collection of the coding training program scores, the results of the analysis of the score data from each coding training participant prove that the participants' scores are increasing every day. Data analysis results can be seen in the figure 3 above. This proves that the ability of participants in typing syntax coding has increased along with the intensity of participants in implementing this coding training program.

The author believes that this gamification method is suitable to be applied to all students who have just joined Informatics Engineering, Riau University so that it can help them improve coding skills which are very much needed in carrying out the 4-5-year learning process in the Informatics Engineering program, Riau University.

\section{STUDENT SCORE FOR CODING PROGRAM}

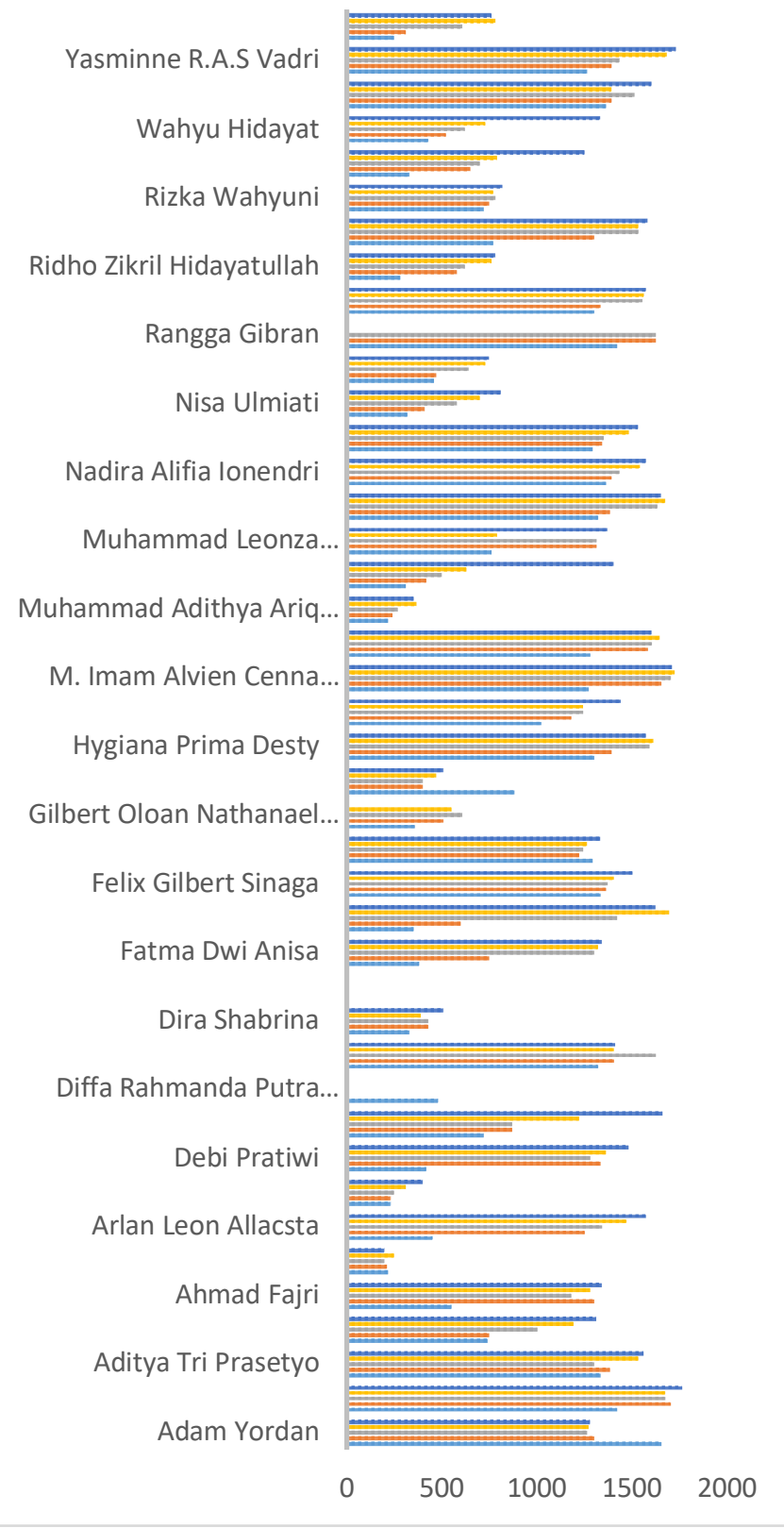

Fig. 6. Coding Training Program Analysis Results 


\section{SugGestion}

After conducting the analysis, the author conducted a questionnaire to ask for criticism and suggestions from the coding training participants. From the results of this questionnaire, it was found that $64.4 \%$ of information technology students at the University of Riau felt the benefits of the coding training program for the development of their coding skills. As many as $31.1 \%$ of students stated that this coding training program was interesting and had the potential to be developed and the remaining $4.5 \%$ had not benefited from this coding training program.

\section{CONCLUSION}

The gamification method is proven to be effective in improving the coding skills of students in the informatics engineering study program. The benefits felt by participants include increasing coding speed, increasing concentration and confidence in typing coding and knowing the basics of programming syntax.

\section{REFERENCES}

[1] Y. Vianna, M. Vianna, B. Medina, and S. Tanaka, Gamification, Inc. Recreating companies through games, 2014th ed. Rio de Janeiro: MJV Tecnologia Ltda, 2014.

[2] K. M. Kapp and J. Coné, What Every Chief Learning Officer Needs to Know about Games and Gamification for Learning. 2012.

[3] I. Glover, "Play as You Learn: Gamification as a Technique for Motivating Learners," 2013.

[4] J. A. Fredricks and W. McColskey, "The Measurement of Student Engagement: A Comparative Analysis of Various Methods and Student Self-report Instruments," in Handbook of Research on Student Engagement, 2012, pp. 763782.
[5] G. Zichermann, Gamification Master Class. O’Reilly Media, 2011.

[6] G. Zichermann and C. Cunningham, Gamification by Design: Implementing Game Mechanics in Web and Mobile Apps. Sebastopol: O’Reilly Media, 2011.

[7] S. Deterding, D. Dixon, R. Khaled, and L. Nacke, From Game Design elements to Gamesfulness: Defining Gammification. Mindrek, 2011.

[8] M. A. Suparman, Desain Instruksional Moderen: Panduan Para Pengajar dan Inovator Pendidikan, 4th ed. Jakarta: Erlangga, 2014.

[9] A. K. Hahne, R. Benndorf, P. Frey, and S. Herzig, Attitude towards computer-based learning: Determinants as revealed by a controlled interventional study. Medical Education, 2005.

[10] L. De-Marcos, A. Domingues, J. Saenz-deNavarrette, and C. Pages, an empirical study comparing gamification and social networking on elearning. Elseiver: Computers \& Education, 2014.

[11] L. De-Marcos, E. Garcia-Lopez, and A. GarciaCabot, On the effectiveness of game like and social approaches in learning: Comparing educational gaming, gamification \& social networking. Elsevier: Computers \& Education, 2016.

[12] S. L. Hoskins and J. C. van Hooff, "Motivation and ability: Which students use online learning and what influence does it have on their achievement," British Journal of Educational Technology, vol. 2, no. 36, pp. 171-192, 2005.

[13] Menteri Pendidikan Republik Indonesia, "Keputusan Menteri Pendidikan Republik Indonesia No 045/U/2002 tentang Pedoman Penyusunan Kurikulum Pendidikan Tinggi dan Penilaian Hasil Belajar Mahasiswa," Jakarta, 2002.

[14] IEEE Computer Society, IEEE Computing Curriculla. United States, 2005.

[15] Teknik Informatika Universitas Riau, Borang IIIA Akreditasi Program Studi Teknik Informatika Universitas Riau. Pekanbaru, 2018. 